\title{
HUBUNGAN KUANTITATIF ANTARA STRUKTUR DAN TOKSISITAS SENYAWA KLOROFENOL
}

\author{
Emdeniz \\ Jurusan Kimia FMIPA Universitas Andalas
}

\begin{abstract}
Quantitative Structure-Activity Relationship (QSAR) for the toxicity of chlorophenols (CPs) from mono to pentachlorine substituted compounds has been done. The structural parameters are obtained from geometry structure optimization by computational chemistry using ab initio methods and the experimental data of acute toxicity $\left(-\log \mathrm{EC}_{50}\right)$ of chlorophenols to Daphnia magna were taken from the literature. The best QSAR model obtained by multilinier regression analysis, using the systematic approach for variable selection and the result showed that QSAR equations i.e:

$$
\begin{aligned}
-\log \mathrm{EC}_{50 \text { pre }}= & -99.545-83.402 \mathrm{r}_{\mathrm{OH}}+145.879 \mathrm{r}_{\mathrm{CO}}-0.053 \mathrm{qo}+26.198 \mathrm{q}_{\mathrm{H}}+0.568 \mathrm{E}_{\mathrm{H}}- \\
& 2.599 \mathrm{E}_{\mathrm{L}}-0.067 \mathrm{HE}-0.134 \mathrm{Rm}+0.133 \mu
\end{aligned}
$$$$
\left(\mathrm{n}=18, \mathrm{R}=0.971, \mathrm{R}^{2}=0.943, \mathrm{SD}=0.447794, \mathrm{~F}_{\mathrm{cal}} / \mathrm{F}_{\mathrm{tab}}=3.956\right)
$$

Keywords: Chlorophenol, QSAR, toxicity

\section{DAFTAR PUSTAKA}

1. M. D. Greca, P. Monaco, G. Pinto, A. Pollio, L. Previtera, and F. Temush, Phytotoxicity of low-molekular-weight phenols from olive mill wastewater, Bull Environ. Contam. Toxicol., 67, 352-359, (2001).

2. U. J. Strotmann and H. Eglsaer, The toxicity of substituted phenols in nitrification inhibition test and luminescent bacteria test, Ecotoxicol Environ. Saf., 30: 26-27, (1995).

3. E. Cohen, A.Gamliel, and J. Katan, The fungitoxicity of chlorophenols to pathogenic fungi, fusarium oxysporum dan rhizoctania solani: a structure activity relationship study, Pestic.Sci., 24: 139-146, (1988).

4. Y. F. Peny and T. B. Liu, QSAR Study of Halogen Phenols Toxicity to Tetrahymena Pyriformis, Chinese $J$. Struct. Chem., 28(2): 218-222, (2009).
5. T. Kishino and K. Kobayashi, Acute toxicity and structure activity relationship of chlorophenols in fish, Water Res., 30: 387-392, (1996).

6. J. Padmanabhan, et al., Group philcity and electrophilicity as possible descriptors for modeling ecotoxicity applied to chlorophenola, Chem. Res. Toxicol., 19: 356-364,(2006).

7. J. Devillers and P Chambon, Acute toxicity and QSAR of chlorophenols on Daphnia magna, Bull. Environ. Contam. Toxicol., 37: 599-605, (1986).

8. HyperChem ${ }^{\circledR}$ Release 7.0 for Windows, HyperCube Inc., Toronto Canada, (2002).

9. D. Priyatno, Paham analisis statistik data dengan SPSS, Media Kom, Yokyakarta, 2010.

10. S. Santoso, SPPS 10: Mengolah data statistik secara profesional, PT Elex Media Komputindo Jakarta, 2001. 
